\title{
WYZWANIA DLA POLSKI - 25 LAT PO ODZYSKANIU SUWERENNOŚCI
}

\section{WPROWADZENIE}

Myślenie o wyzwaniach dla Polski w ćwierć wieku po odzyskaniu suwerennej państwowości powinno się zaczynać od choćby najkrótszej oceny stanu posiadania, czyli tego, co się udało osiaggnąć w tym okresie. I tu się zaczyna podwójna trudność. Po pierwsze, Polacy generalnie mają skłonność do niedoceniania swoich osiagnięć po $1989 \mathrm{r}$. W dyskursie publicznym dominuje podkreślanie słabości, grzechów, zaniechań w polityce tego czasu. Pojawiają się też oskarżenia znacznie poważniejsze (wyprzedaż za bezcen majątku narodowego, oddanie suwerenności do Brukseli czy wizja Polski jako kondominium...). Mówienie o sukcesie Polski nie jest w dobrym tonie, w żadnym środowisku ${ }^{1}$. Po drugie, jeśli już nawet uda się obronić tezę o generalnie dodatnim bilansie przemian, o solidnych podstawach bezpieczeństwa, wzrostu gospodarczego, dobrych relacjach $\mathrm{z}$ otoczeniem, to natychmiast pytania, skąd te wyzwania. Jeśli wyzwania, tzn. że polskie sprawy na scenie europejskiej nie wyglądaja dobrze, że aktualnie rządzący nie zdają egzaminu z obrony polskich interesów. Słyszymy np., że jeśli dla wzmocnienia bezpieczeństwa Polski warto wchodzić do strefy euro jako twardego rdzenia integracji europejskiej, oznacza to, że dotychczasowa polityka bezpieczeństwa była błędna i nieskuteczna.

Nie zamierzam jednak dać się odstraszyć zawodowym „analitycznym” malkontentom ani środowisku przywiązanemu do polskich klęsk. Uważam, że minione ćwierćwiecze było najbardziej korzystnym czasem dla Polski w całych jej ponadtysiącletnich dziejach. Bardziej rzetelne udokumentowanie tej tezy wymagałoby odrębnego tekstu porównujacego ostatnie dwadzieścia pięć lat z kilkoma wybranymi okresami uważanymi przez historyków za porównywalnie udane $\mathrm{w}$ naszej historii. Tutaj ograniczę się do stwierdzenia, że dopiero teraz, po 1989 r., staliśmy się integralna, jednogatunkową częścią Europy, nawet jeśli pod względem wielkości PKB per capita zaledwie przekraczamy 60\% europejskiej (UE) średniej. Staliśmy się częścią Europy przede wszystkim w sensie ustrojowym. Polski ustrój polityczny i gospodarczy oraz model społeczny odpowiadają europejskim, instytucjonalnym standardom (III RP). Pod tym względem dołączyliśmy do Europy czy też do świata zachodniego znacznie

${ }^{1}$ Dla porównania zob. artykuł bardzo pozytywnie oceniający rezultaty polskich przemian po 1989 r.: M. A. Orenstein, Poland: From Tragedy to Triumph, „Foreign Affairs”, styczeń/luty 2014. 
szybciej, niż można się było spodziewać w roku zero, tzn. w 1989 r. Już w listopadzie $1991 \mathrm{r}$. Polska stała się członkiem Rady Europy, która w tamtym czasie była surowym strażnikiem standardów w sferze demokracji, praworządności i poszanowania praw człowieka (dziś już nim nie jest). W 1996 r. staliśmy się członkiem OECD, która pełni tę samą funkcję (do dzisiaj) w odniesieniu do modelu otwartej, liberalnej gospodarki rynkowej. Oba te wymiary ustroju wraz z różnymi szczegółami organizacji życia społecznego przeszły rygorystyczny test w procesie negocjowania członkostwa w UE (,kryteria kopenhaskie”), zakończonym skutecznie w grudniu 2002 r. Nie oznacza to bynajmniej, że proces dochodzenia do europejskich standardów w sferze ustroju politycznego i modelu gospodarczego był wolny od błędów, kryzysów czy afer. Były one jednak przede wszystkim pochodną przejścia międzysystemowego (transformacji), które zawsze wiąże się z kosztami społecznymi i gospodarczymi oraz błędami w trakcie uczenia się nowego ustroju. Ponadto uruchomienie źródeł wzrostu z sytuacji gospodarczej ruiny pozostawionej przez PRL nieuchronnie wyzwalało instynkty i sytuacje patologiczne, pogłębiało nierówności, tworzyło obszary nędzy, destabilizowało scenę polityczna. A co się tyczy społecznych kosztów sukcesu w sferze gospodarczej, to były one niemałe: duże bezrobocie i duża emigracja, zwłaszcza ludzi młodych, wykształconych, energicznych oraz niski przyrost naturalny. Te koszty będą odczuwalne jeszcze przez dziesięciolecia.

Przemianom wewnętrznym dającym nam pełną europejską tożsamość cywilizacyjną (wartości, normy, standardy) towarzyszyło włączanie się w wytworzona w czasach zimnej wojny, czyli bez udziału Polski, strukturę instytucjonalną jednocząca Europę Zachodnią i cały Zachód. Przyjęta przez Tadeusza Mazowieckiego i Krzysztofa Skubiszewskiego linia polityki zagranicznej (jednoznaczny kierunek na Zachód - „powrót do Europy”) przyniosła szybko owoce w postaci członkostwa w Radzie Europy, stowarzyszenia ze Wspólnotami Europejskimi, które skutecznie „wprowadziło” nas do Unii Europejskiej, historycznego traktatu z Niemcami, który jest fundamentem procesu pojednania polsko-niemieckiego ${ }^{2}$. Podobnie szybko udało się nam włączyć w obręb bliskiej współpracy z Sojuszem Atlantyckim, która doprowadziła do szybkiego członkostwa w NATO oraz ścisłej współpracy z USA w sferze bezpieczeństwa. Oba te kręgi instytucjonalne dały Polsce najwyższe spośród realnie istniejących zewnętrzne gwarancje bezpieczeństwa oraz osnowę gospodarczego i cywilizacyjnego rozwoju. Niczego lepszego, pewniejszego na świecie nie ma. Jednocześnie doszło do normalizacji stosunków z państwami Europy Wschodniej w sposób, dzięki któremu ich polityka przestała stanowić zagrożenie dla Polski. Stało się tak, pomimo nieprzyjaznych gestów ze strony Rosji oraz niekorzystnych procesów politycznych na Białorusi i Ukrainie. Zarazem nawroty do „jagiellońskiej” retoryki w polityce polskiej nie przeszkodziły w urzeczywistnianiu linii „piastowskiej” (Mazowieckiego-Skubiszewskiego), czyli zakorzenianiu Polski w Europie (UE). Umiejętne ułożenie stosunków z otoczeniem sprawiło, że użycie siły przeciwko Polsce przestało być problemem polityki bezpieczeństwa RP.

2 T. Mazowiecki, Rok 1989 i lata następne, Warszawa 2012; K. Skubiszewski, Polityka zagraniczna i odzyskanie niepodlegtości. Przemówienia, oświadczenia, wywiady 1989-1993, Warszawa 1997. 


\section{NIEKTÓRE WYZWANIA WEWNĘTRZNE}

Ze względu na granice kompetencji nie będę rozwodził się o wyzwaniach wewnętrznych. Jednak od tego, jak się z nimi uporamy, będzie zależeć polska zdolność do stawiania czoła wyzwaniom zewnętrznym. Dlatego subiektywnie wybrałem trzy problemy, których rozwiązywanie będzie mieć w dłuższej perspektywie wielkie znaczenie dla pozycji międzynarodowej Polski.

Po pierwsze, dojrzałość i funkcjonalność naszego systemu politycznego. Polska polityka, przy całej towarzyszącej jej egzotyce i hałaśliwych skrajnościach, zdawała po 1989 r. całkiem dobrze egzamin w warunkach „zewnętrznego naprowadzania" na osiaganie strategicznie ważnych celów. Dotyczyło to przede wszystkim właśnie członkostwa Polski w UE i NATO. Wprawdzie oba te cele były polskim wyborem, ale tempo i sposób realizacji były określane z zewnątrz. To przypominało współpracę między pilotem dużego samolotu a wieżą kontrolną lotniska. Bezpieczne lądowanie zależało od instrukcji kontrolera lotu. Było tak, nawet jeśli cel został uzgodniony przez załogę i pasażerów lotu, którzy w odniesieniu do niemal wszystkich innych spraw pozostawali w głębokiej niezgodzie. Po wylądowaniu w Brukseli (NATO, UE) konsensus na pokładzie się skończył.

Od połowy poprzedniej dekady polityka polska, wprawdzie nadal stabilna i obliczalna, znalazła się w stanie dysfunkcjonalności. Ujmując rzecz inaczej, system polityczny stał się dysfunkcjonalny wobec konieczności rozwiązywania wielkich problemów i podejmowania ważnych reform, wobec stawiania czoła poważnym wyzwaniom. Stało się to za sprawą niemal religijnej wojny politycznej rozpętanej w kraju przez główną od 2007 r. partię opozycyjną oraz płytkości politycznego myślenia. Zwłaszcza od czasu katastrofy prezydenckiego samolotu w kwietniu 2010 r. pod Smoleńskiem radykalizm politycznego podziału uniemożliwia porozumienie w sprawach dla Polski podstawowych. Nie może być inaczej, skoro rząd i prezydent są oskarżani mniej czy bardziej wprost o doprowadzenie do zamachu na prezydenta Lecha Kaczyńskiego, i to najpewniej w spisku z władzami Rosji. To uparcie lansowane „kłamstwo smoleńskie” zatruwa polskie życie publiczne, a jego cień w postaci oskarżeń o „zdradę i spisek" uniemożliwia jakąkolwiek współpracę, bez której nie da się podejmować ważnych reform, uprawiać odważnej polityki (istnienie mniejszości blokującej w parlamencie). Należy zakładać względną trwałość tego podziału, który przenosi się na wiele dziedzin życia publicznego. Katastrofa smoleńska stała się centralna kwestią polityki polskiej. Przy czym o ile w sporze pomiędzy trumnami Piłsudskiego i Dmowskiego chodziło o sprawy programowe, o tyle funkcją trumny Kaczyńskiego stała się próba delegitymizacji legalnych, demokratycznie wybranych władz Rzeczypospolitej i próba uniemożliwienia im normalnego rządzenia. Lider opozycji odmawia udziału w Radzie Bezpieczeństwa Narodowego, a jego partia zapowiada sprzeciw wobec reform umożliwiających Polsce przystapienie do strefy euro.

Na niemal religijny charakter smoleńskiego sporu nakłada się banalizacja i tabloidyzacja dyskursu politycznego w Polsce w ogóle. Poważne debaty maja miejsce na obrzeżach naszego życia politycznego, centrum zaś opanowane jest 
przez spór o historyczne rocznice, stosunek do przeszłości, prawo do świętowania 11 Listopada itp. Rządzący ogłosili programowe unikanie refom (ewentualne koszty reform są gwarancją wyborczej porażki), a opozycja powrót do pokracznego projektu IV RP i rozliczenie zdrajców (po zdobyciu władzy), media zaś, nawet głównego nurtu, w trosce o oglądalność i nakłady podgrzewaja atmosferę. Myśl państwowa, jej rozległe horyzonty, zdolność do przywództwa wyparowały, a przynajmniej nie sa w stanie się przebić na powierzchnię politycznego dyskursu i do opinii publicznej. Postępująca dysfunkcja systemu politycznego nie jest błahym problemem ${ }^{3}$, w gruncie rzeczy bowiem chodzi o zdolność do strategicznego działania, do mobilizowania społeczeństwa, do podejmowania decyzji niepopularnych, krótkookresowo bolesnych, lecz niezbędnych dla przyszłego rozwoju i miejsca Polski.

Drugim wewnętrznym wyzwaniem jest doprowadzić do końca europeizację Polski w sensie cywilizacyjnym. Wprawdzie Polska spełniła dość szybko minimalne i nominalne zarazem normy i standardy umożliwiajace nam członkostwo w UE (znacząco pomogła przy tym sprzyjająca nam historyczna koniunktura), lecz do faktycznej średniej europejskiej we wszystkich niemal dziedzinach życia społecznego droga daleka. Gdyby było inaczej, nie musielibyśmy otrzymywać (i walczyć o nie jak o niepodległość) potężnych funduszy z budżetu UE. Gros tych pieniędzy pochodzi z funduszy spójnościowych, czyli właśnie tych, które służą wyrównywaniu standardów życia w obrębie Unii. Te fundusze sa nie tylko w ogromnym stopniu odpowiedzialne za wzrost gospodarczy Polski w ostatnich latach (pobudzają inwestycje), lecz także czynią w Polsce „więcej Europy”. Tych pieniędzy nie wolno przejadać, np. na aquaparki czy ścieżki turystyczne. Muszą pójść na podnoszenie poziomu edukacji, badań rozwojowych (R\&D), ochrony zdrowia, sprawności administracji, infrastrukturę transportowo-telekomunikacyjną czy ochronę środowiska. Muszą nas upodabniać do pozostałych państw Unii, zwłaszcza „starej” Unii, pod względem poziomu cywilizacji materialnej i umysłowej, a jednocześnie zwiększać szanse szybkiego i zrównoważonego rozwoju już po ustaniu unijnej „kroplówki”“. Unijne fundusze muszą być sprzężone z reformami wewnętrznymi, które zapobiegną utknięciu Polski w „pułapce średniego poziomu rozwoju”. Chodzi o takie zmiany instytucjonalne (reformy właśnie), które stworza środowisko sprzyjajace rozwojowi gospodarczemu na poziomie 4-6\% rocznie, bez którego przestaniemy zbliżać się do średniej europejskiej, bez czego nie utrwalimy swego miejsca w "twardym jądrze” integracji europejskiej i jego form instytucjonalnych ${ }^{5}$. Tego rodzaju europeizacja Polski nie tylko nie zagraża naszej tożsamości, jak mogą twierdzić antyunijni fundamentaliści, ale wręcz daje jej mocniejsze podstawy, jak Francuzom, Holendrom czy Szwedom.

\footnotetext{
${ }^{3}$ Odstraszanie rządzących od reform czy odważnych decyzji jest takim samym przejawem dysfunkcji systemu politycznego jak parlamentarny filibuster w USA. Inną sprawa jest brak odwagi rządzacych podejmowania takich decyzji (rozmowy ze społeczeństwem o konieczności ich podjęcia).

${ }^{4}$ P. Świeboda, Strach może być pułapka. Co przeszkadza nam gonić Unię, „Gazeta Wyborcza” z 11 października $2013 \mathrm{r}$.

${ }^{5}$ Raport „Konkurencyjna Polska. Jak awansować w światowej lidze gospodarczej?” (J. Hausner et al.), Kraków 2013. Raport powstał z inspiracji Prezydenta RP.
} 
Tego rodzaju europeizacja (modernizacja) pozwoli lepiej wykorzystać tkwiacy w Polakach potencjał rozwojowy i wzmocni międzynarodową pozycję naszego kraju. Zarazem wzmocni nasze ogólne bezpieczeństwo wobec Europy Wschodniej oraz będzie wywoływać pobudzający ją do zbliżenia z Europą Zachodnia efekt demonstracji (zwłaszcza u Białorusinów i Ukraińców).

Trzecim wyzwaniem, które musi być szybko i skutecznie w Polsce podjęte, jest odwrócenie skrajnie niedobrych tendencji demograficznych. Ze wskaźnikiem dzietności poniżej 1,4\% (przy trochę powyżej 2\% niezbędnych dla zastępowalności pokoleń) Polska zajmuje jedno z ostatnich miejsc w UE. Niezdolność do odwrócenia tej tendencji w średniej, a zwłaszcza dłuższej perspektywie będzie pociągá za sobą głębokie, negatywne gospodarcze, społeczne i cywilizacyjne konsekwencje. Starzenie się społeczeństwa prowadzi nieuchronnie do spadku witalności gospodarczej i kulturowej. To sa zależności zbyt dobrze rozpoznane, aby je tutaj dodatkowo argumentować. Nastapi także osłabienie pozycji międzynarodowej Polski. Nasz kraj nie ma wyboru. Musi za niemal każdą cenę przyjąć w najbliższych latach rozwiązania prorodzinne oraz skutecznie zachęcajace młodych ludzi do pozostawania w kraju, które to rozwiązania zapobiegną rysującej się w perspektywie 30-50 lat katastrofie demograficznej Polski. Jeśli jej nie zdołamy zapobiec, postęp w innych dziedzinach będzie miał drugorzędne znaczenie ${ }^{6}$. W żadnym $\mathrm{z}$ aspektów, od gospodarczego po kulturowy, imigracja nie zastapi samych Polaków w odpowiedzialności za przyszłość Polski.

\section{EUROPEJSKIE WYZWANIA POLSKI, CZYLI JAKA EUROPA PO KRYZYSIE}

Polityka zagraniczna RP po 1989 r. okazała się sukcesem w odniesieniu do podstawowych zagadnień każdej polityki zagranicznej: bezpieczeństwa, warunków rozwoju, pozycji międzynarodowej państwa ${ }^{7}$. Jednakże od końca pierwszej dekady XXI w., zwłaszcza od kryzysu finansowego, który wybuchł w 2008 r., jesteśmy świadkami wydarzeń wprowadzających istotne zmiany do środowiska międzynarodowego Polski, we wszystkich jego głównych segmentach. I w każdym przypadku sa to zmiany na gorsze. Po pierwsze, chodzi o przeciagający się i najgłębszy od traktatów rzymskich kryzys i zmiany instytucjonalne w UE. Po drugie, polityczny regres w krajach Europy Wschodniej będących naszymi bezpośrednim sąsiadami. Po trzecie, strategia przenoszenia przez Stany Zjednoczone punktu ciężkości swego zainteresowania do Azji Wschodniej w celu równoważenia rosnącej potęgi Chin; dodać do tego należy słabnięcie globalnego przywództwa USA. Po czwarte, ruszyła przebudowa porządku międzynarodowego w kierunku odbiegającym od wartości i interesów Zachodu (post-Western world), co z jednej strony należy uznać za normalne zjawisko, ale z drugiej - oznacza, że krajom zachodnim, w tym Polsce, trudniej

${ }^{6}$ S. Kluza, Polska musi mieć politykę prorodzinna, „Rzeczpospolita” z 19 lutego 2013 r.; B. Marczuk, Rok 2013. Polska wymiera, „Rzeczpospolita” z 17 czerwca 2013 r.

7 Zob. szerzej R. Kuźniar, Polityka zagraniczna III Rzeczpospolitej, Warszawa 2012. 
będzie osiagać swoje cele. Wszystkie te zmiany nie pociagaja za sobą bezpośrednich, poważnych zagrożeń dla Polski, zwłaszcza dla jej bezpieczeństwa, ale długofalowo będą komplikować i utrudniać urzeczywistnianie naszych narodowych interesów. Nie sposób odnieść się w tak krótkim tekście do wszystkich dużych wyzwań, jakie wiążą się z powyższymi zmianami, a przecież ich lista może być dłuższa. Kierując się ludową mądrością: bliższa ciału koszula, skoncentruję się na trzech z nich, wszystkich europejskich.

1. Unia Europejska znajduje się od końca poprzedniej dekady w głębokim kryzysie. Właściwiej jest nawet mówić o Europie wielu kryzysów: finansowo-gospodarczego, polityczno-instytucjonalnego oraz ideowo-cywilizacyjnego (tożsamości). Jednym z rezultatów tej złożonej kryzysowej sytuacji stało się przyśpieszone wejście w Europę kilku prędkości, w Europę zmiennej geometrii. Zasadniczo możemy mówić obecnie o Europie dwóch prędkości, co polega na pojawieniu się „twardego rdzenia”, którym jest strefa euro. To, że pojawi się Europa kilku prędkości, zapowiadano przynajmniej od połowy lat dziewięćdziesiątych poprzedniego stulecia, a to $\mathrm{w}$ związku z nagłym wzrostem liczby członków UE - do 1994 r. było ich 12, a od 2004 r. (de facto 2002 r.) - już 25. Przypomnijmy, że Wspólnota zaczynała w 1957 r. (de facto w 1951 r.) w sześć państw. Zróżnicowanie interesów oraz gotowość i zdolność do uczestnictwa w różnych kręgach integracji w tak dużej grupie państw musiały prowadzić do pojawienia się różnych prędkości w procesie integracji, a przede wszystkim jej „twardego rdzenia”, którym okazała się strefa euro. Kryzys finansowy w strefie euro po 2009 r. oraz sposoby jej ratowania, w tym ratowania tych państw członkowskich, które go spowodowały, zapoczątkował proces federalizacji UE, nie całej, ale przynajmniej strefy euro, co zaczęło się od przyjęcia paktu stabilności w 2012 r. Na końcu tego procesu uzdrawiania i stabilizowania strefy, po ustanowieniu unii finansowej, gospodarczej i bankowej, ma się pojawić unia polityczna. Instytucjonalna konsolidacja strefy euro czyni z niej nieodwołalnie „twardy rdzeń” integracji. Państwa, które do niej nie przystapia, staną się drugim, czy też zewnętrznym, kręgiem w łonie UE. Najważniejsze decyzje będa podejmowane w kręgu wewnętrznym i z udziału w nim wynikać będą największe pożytki. Kto się nie zdecyduje czy też nie zdoła być „w”, będzie „poza”, ze wszystkimi tego politycznymi konsekwencjami. Od 1 stycznia 2014 r. w skład strefy wejdzie także postsowiecka Łotwa, jako jej 18 państwo członkowskie (z krajów byłego bloku komunistycznego jest już także Słowacja i Słowenia).

Korzyści z udziału w strefie euro (przejścia na euro) sa przynajmniej trojakiego rodzaju: stabilność makrofinansowa, bezpieczeństwo gospodarcze oraz udział w wewnętrznym kręgu integracji europejskiej. W obliczu tych zmian Polska musi zmierzyć się z wyzwaniem wejścia do strefy euro lub pozostania na peryferiach. Bezdyskusyjnie bardziej korzystny jest wariant pierwszy (dyskutować można i warto o detalach, ale nie o istocie wyboru). W obliczu instytucjonalnego „zagęszczania się” strefy euro Polska zajęła postawę w najlepszym przypadku niefrasobliwa. W pierwszej fazie kryzysu w strefie euro polski rząd głosił, że nie można rozważać przystapienia do euro, dlatego że „nie wchodzi się do domu, który jest ogarnięty pożarem”. Później, kiedy „pożar” dogasał i kraje strefy zaczęły tworzyć instytucje służące bezpieczeń- 
stwu strefy i wspólnej waluty UE w przyszłości, Warszawa ogłosiła doktrynę „trzymania nogi w drzwiach”, tzn. niewchodzenia do strefy, ale podpisywania niektórych dokumentów ustanawiajaccych te nowe instytucje, aby mieć wgląd w dalszy rozwój strefy i w razie jakichś dalszych, wykluczających nas ze ścisłego kręgu kroków protestować. Jednocześnie Polska deklarowała zamiar przystapienia do euro w ciagu kilku lat (np. w latach 2016-2017) i w tym celu nawet pozorowała podjęcie pewnych kroków przygotowawczych. W $2013 \mathrm{r}$. porzucono pozory, a „doktryna trzymania nogi w drzwiach” stała się nieaktualna, gdyż niewiarygodna. Powody tej rejterady są dwa. Pierwszy, negatywna postawa większości opinii publicznej (w różnych sondażach ok. 60\% przeciw i ok. 30\% za) i obawa rządu, że wejście na drogę przygotowań do euro może pogorszyć szanse wyborcze partii rządzącej. Rząd uląkł się także „ognia zaporowego” głównej partii opozycyjnej, która zapowiedziała kategoryczny sprzeciw i że nie dopuści do zmian w Konstytucji, które zdaniem wielu są niezbędne, aby przyjąć w Polsce wspólną walutę UE. Obawiając się porażki na tym tle, rząd nie chciał czynić ze sprawy wejścia do euro głównego tematu walki wyborczej w latach 2014-2015 (wybory do Parlamentu Europejskiego oraz do Sejmu). Powód pierwszy, politycznie dyskusyjny, ale zrozumiały. Ale był też drugi powód. W ostatnich latach, pomimo stałego wzrostu gospodarczego, Polska zaczęła się oddalać od kryteriów przystapienia do strefy euro. Reformy, które były konieczne, aby spełnić te kryteria (zwłaszcza restrykcyjna polityka finansowa), pociagałyby za sobą w pierwszej fazie koszty społeczne. Ponadto minister finansów woli dysponować własną waluta, aby za pomoca zmiany jej kursu wpływać na eksport-import, czyli także na wzrost gospodarczy. To jest łatwiejsze niż osiaganie go reformami z zakresu finansów publicznych czy rynku pracy. Inne wyzwanie, o którym tutaj nie ma mowy, poprawa konkurencyjności polskiej gospodarki - może się dokonać tylko przez reformy, które są niezbędne, aby sprostać kryteriom przystapienia do strefy euro.

Rząd pod naciskiem ministra finansów poniechał wszelkich reform, które mogłyby nas przybliżyć do warunków członkostwa w strefie euro. Szansa, aby to uczynić kilka lat temu, nawet zaraz na początku drugiej kadencji rządu PO-PSL, została zmarnowana. Do sprawy być może będzie można wrócić po wyborach w 2015 r., w zależności od ich wyniku. Dzisiaj mówi się, że wejście Polski do strefy euro może nastapić najszybciej w okolicach 2020 r. (zgodnie z obietnica premiera Tuska z września 2008 r. Polska miała się tam znaleźć od 1 stycznia 2012 r.). To także nie jest pewne. Tymczasem strefa euro będzie podlegać takim instytucjonalnym zmianom, że przyłączenie się do niej takiego kraju, jak Polska będzie nadzwyczaj trudne. Łatwiej będzie w niej być takim krajom, jak Grecja czy Portugalia, niż przystapić do niej krajom takim jak Polska. Argumenty populistyczne oraz polityczne kunktatorstwo leżą u podstaw tej porażki polskiej polityki przełomu pierwszej i drugiej dekady naszego stulecia. W ocenie znakomitej większości bezpartyjnych ekspertów oraz zdaniem polskich przedsiębiorców korzyści wynikające z przynależności do strefy euro są bezsporne. Są na ten temat liczne publikacje i raporty ${ }^{8}$. Koszty, jeśli w ogó-

${ }^{8}$ Np. M. Dunin-Wassowicz, A. Darska, G. Tchorek, Integracja europejska i nowy ład gospodarczy, Warszawa 2012. 
le, sa krótkookresowe, członkostwo w strefie euro zaś jest zarówno korzystne dla obywateli, jak i zgodne z długofalowymi interesami Polski. W takich sytuacjach rząd musi mieć odwagę rozmowy z własnym społeczeństwem, musi mieć odwagę - po wyłożeniu wszystkich racji - podejmować decyzje niepopularne. Dotyczy to także opozycji, która w sprawach będących częścią racji stanu musi się wznosić ponad logikę walki politycznej i mieć odwagę ponosić współodpowiedzialność za decyzje należące do tej kategorii. Tego w Polsce zabrakło. Przełamanie tej niemożności jest wielkim wyzwaniem stojącym przed polityka polską w najbliższych latach. Stawką jest bezpieczny rozwój Polski, jej bezpieczeństwo finansowe oraz współdecydowanie o kształcie integracji europejskiej i jej instytucjonalnej formule - Unii Europejskiej.

2. Przynależność do grupy państw stanowiących „twardy rdzeń” integracji europejskiej jest warunkiem zdolności do wywierania wpływu na jej dalszy kształt oraz na przyszła tożsamość Wspólnoty. Polska, jako jeden z większych krajów UE, ale również ze względów historycznych i geopolitycznych powinna mieć klarowną wizję przyszłości Wspólnoty i procesu integracji. Nasza przyszłość zależy w większym stopniu od kształtu i mocy UE, niż jest to w przypadku wielu innych państw członkowskich. Polska na razie tej wizji nie ma. Owszem były, zwłaszcza w czasie polskiej prezydencji w Radzie UE w drugiej połowie 2011 r., liczne wypowiedzi na wysokim szczeblu, ale nie złożyły się one na całościowy projekt. Był w nich także eurooptymizm. Teraz nie ma ani jednego, ani drugiego. W pytaniu o przyszłość UE zawierają się przynajmniej trzy duże zagadnienia: 1) jej polityczno-instytucjonalny kształt, 2) fundament duchowo-aksjologiczny, 3) rola międzynarodowa.

W odniesieniu do pierwszej kwestii, rzecz z grubsza biorąc, chodzi o głębokość integracji UE oraz sposób zarządzania nią (governance). W związku $\mathrm{z}$ kryzysem $\mathrm{w}$ strefie euro zupełnie otarcie postawiona została sprawa federalnego charakteru Unii. Unia już w tej chwili jest forma płytkiej federacji międzynarodowej, nawet jeśli tego tak się wprost nie nazywa ze względu na „alergię" niektórych państw czy środowisk na samo pojęcie federacji. Ono istotnie w odniesieniu do UE nie jest najbardziej szczęśliwe. Abstrahując od samej nazwy, którą można zastapić bardziej „niewinna”, jak np. unia polityczna, dla strefy euro od pogłębienia jej federalnego charakteru nie ma, jak się zdaje, odwrotu. Ale nawet jeśli chcemy jeszcze przez jakiś czas uciekać od sporu o federalizm UE, już teraz musimy zajacc stanowisko wobec słabnięcia metody wspólnotowej (uosabianej głównie przez KE) na rzecz wzmacniania metody międzyrządowej, czyli roli Rady, a zwłaszcza Rady Europejskiej. Możemy wprawdzie narzekać, że metoda wspólnotowa (w tym PE) obciążona jest deficytem demokratycznym, ale to właśnie ona stoi na straży interesów krajów słabszych i słabiej rozwiniętych. Metoda międzyrządowa ma swoje zalety, ale też jej użycie i efekty zależą od aktywności i woli państw najsilniejszych unijnych mocarstw. Polska do tej pory starała się łączyć zalety obu metod, ale jeśli nie staniemy się uczestnikiem unijnej pierwszej prędkości (euro), to w ramach metody międzyrządowej staniemy się członkiem drugiej kategorii. 
Powinniśmy wiedzieć, na co stawiamy, aby wkrótce nie stać się w Unii państwem pukającym do różnych drzwi, któremu hamletowskie niezdecydowanie nie pozwoli zajacc miejsca w centrum europejskiego projektu.

Jeszcze trudniejszą sprawą niż optymalny dla jej obecnej fazy rozwoju porządek ustrojowy Unii Europejskiej jest kwestia jej cywilizacyjno-politycznej tożsamości. Z tym w Europie mamy coraz większe kłopoty. Wprawdzie ojcowie założyciele Wspólnoty swoje działania na rzecz jedności Europy wywodzili z chrześcijaństwa ${ }^{9}$, lecz dzisiaj UE definiuje się jako przestrzeń wspólnych standardów gospodarczych i prawnych (rynek plus demokracja i prawa człowieka). Pozbawione ducha standardy ustroju gospodarczego i politycznego nie wystarczą do zbudowania wspólnej europejskiej tożsamości, zwłaszcza gdyby miały homogenizować wyrastający ze wspólnego fundamentu cywilizacyjnego pluralizm narodowo-religijno-kulturowy. Tożsamość nie może się obyć bez przeszłości, bez tradycji, pamięci historycznej, kodu kulturowego, religii lub jej aksjologiczno-ideowego zamiennika. Tak jest w przypadku państwa narodowego i nie wydaje się, aby bez podobnych składników, których Europie nie brakuje, można było zbudować europejską tożsamość, czyli także europejski demos. Obok norm, regulacji i mechanizmów, których czasem jest w nadmiarze, potrzebna jest wspólnota ducha. Co ma ją tworzyć? Tymczasem we współczesnej Europie, zwłaszcza na szczeblu jej instytucji, obserwujemy chęć ucieczki od tożsamości. Jest to o tyle niepokojące, że poza Europą widoczna jest tendencja przeciwna - umacniania się tożsamości czerpiących swoją siłę i witalność z cywilizacyjnych korzeni. Tożsamość jest nie tylko ważna dla chęci i zdolności do przetrwania, ale także dla określania granic Unii Europejskiej oraz dla kształtowania modelu społecznego i gospodarczego rozwoju. Czy bez podzielanej przez uczestników europejskiego projektu zjednoczeniowego wspólnej tożsamości możliwe będzie utrzymanie unikatowego europejskiego modelu społecznego, którego istotą jest zrównoważone współistnienie trzech wartości: wolności - sprawiedliwości - solidarności? Polska historia, tradycja, doświadczenie przemian ostatnich dziesięcioleci powinny nas predestynować do aktywnego współokreślania tożsamości zjednoczonej Europy. Bez prób wywoływania wojen kulturowo-religijnych (np. o krzyż z Brukseli), ale też bez obawy obrony obecności w tej tożsamości wielkich składników chrześcijańskiej tradycji, kształtującej od dwóch tysięcy lat oblicze kontynentu ${ }^{10}$.

Od siły wspólnej tożsamości, czyli również spoistości UE, zależy zdolność do odgrywania przez nią aktywnej roli międzynarodowej. Wszakże już w Traktacie z Maastricht pojawiło się pojęcie „tożsamości międzynarodowej” Unii, której podstawowym instrumentem miała być Wspólna Polityka Zagraniczna i Bezpieczeństwa. Wzmocnieniem tej ostatniej miała być od początku poprzedniej dekady Europejska Polityka Bezpieczeństwa i Obrony. I rzeczywiście, rozwój międzynarodowej tożsamości UE przebiegał całkiem obiecująco, łącz-

\footnotetext{
${ }^{9}$ W stosunku do jednego z nich - Roberta Schumana Kościół katolicki wszczął nawet proces beatyfikacyjny.

${ }_{10}$ Zob. szerzej R. Kuźniar, My, Europa, Warszawa 2013, s. 205-214. (Zob. recenzję tej pracy, autorstwa Z. Czachora i A. Jaskulskiego, „Ruch Prawniczy, Ekonomiczny i Socjologiczny” 2013, z. 3, s. 297-298 - przyp. Redakcji).
} 
nie z pierwszymi udanymi operacjami militarnymi (np. w Kongu w 2003 r.). W europejskim dyskursie pojawiła się jako uprawniona koncepcja Unii jako „globalnego aktora”. Później jednak, zwłaszcza w związku z wewnątrzunijnymi podziałami na tle wojny przeciwko Irakowi oraz upadku Traktatu konstytucyjnego i ostatecznie w związku z kryzysem po 2008 r., międzynarodowa aktywność i skuteczność UE zaczęły się znacząco zmniejszać. Na pierwszy plan globalnej geopolityki wysunęła się formuła G2, czyli Chimeryka, a pozycja i głos Unii stały się słabsze, a nawet w niektórych sytuacjach były ignorowane. W impasie znalazła się także jej polityka bezpieczeństwa i obrony. Nie tylko nie było środków na rozwój zdolności militarnych UE, ale górę zaczęły brać partykularne interesy unijnych mocarstw. W żadnej z ważnych spraw międzynarodowych Unia nie potrafiła zając szybko wyrazistego stanowiska. Sytuacji nie poprawiło przyjęcie Traktatu lizbońskiego, który wprowadzał ważne innowacje instytucjonalne zmierzające do wzmocnienia międzynarodowej roli UE, w tym pozycji przewodniczącego Rady Europejskiej oraz Wysokiego Przedstawiciela ds. Polityki Zagranicznej i Bezpieczeństwa, który łączy to stanowisko z funkcją wiceprzewodniczącego Komisji Europejskiej.

Polska, która nie należy do unijnych mocarstw, lecz jest krajem brzegowym UE (na granicy rządzonego autorytarnie obszaru niepewności i nieprzewidywalności) i zarazem o pewnych ambicjach międzynarodowych, powinna być zainteresowana w umacnianiu zdolności Unii do kształtowania jej zewnętrznego otoczenia. W szczególności jest w interesie Polski zdolność UE do wspierania przemian demokratycznych w jej otoczeniu oraz do stabilizowania tam sytuacji bezpieczeństwa, także - w razie potrzeby - za pomocą instrumentów militarnych w rodzaju misji stabilizacyjnych czy pokojowych. Zważywszy na ewolucję globalnej sytuacji strategicznej, w tym przenoszenie amerykańskiego zaangażowania w tej dziedzinie ku regionowi Azji Wschodniej i Pacyfiku, UE powinna przejmować stopniowo coraz większą odpowiedzialność za własne bezpieczeństwo i obronność. Tylko wtedy będzie wartościowym i koniecznym partnerem USA w ramach szerszego zadania zapewniania bezpieczeństwa Zachodu i stabilności globalnej, we współpracy z NATO i niezależnie od Sojuszu. Jak wiadomo, zarówno w sprawie międzynarodowej roli UE oraz jej roli i zdolności w sferze bezpieczeństwa i obrony istnieją w łonie Wspólnoty znaczne różnice, które sa przyczyną obecnego impasu. Zadaniem Polski jest we współpracy z zainteresowanymi państwami członkowskimi - umacnianie Unii w obu tych wymiarach. Powinna to czynić przez 1) modernizację własnego potencjału militarnego, także inwestując w europejski przemysł obronny (i europeizując tym samym własny), 2) udział w operacjach militarnych Unii oraz 3) usprawnianie swoich polityczno-organizacyjnych mechanizmów w tej dziedzinie (m.in. stały sztab, dostosowana do potrzeb organizacja europejskich sił zbrojnych). Zważywszy na kontynuację w przewidywalnej przyszłości sprzeciwu niektórych państw (zwłaszcza Wielkiej Brytanii) wobec wzmocnienia roli UE w sferze bezpieczeństwa i obrony, jedyną dostępną opcją na dokonanie postępu będzie skorzystanie z dopuszczonej Traktatem lizbońskim formuły współpracy wzmocnionej, tzn. w mniejszej grupie państw. Jeśli okoliczności uczynią to realnym, Polska powinna być jednym z inicjatorów takiego przełomu. 
Trzeba mieć świadomość, że od tego, czy potrafimy umiejętnie połaczyć te trzy składniki: adekwatny kształt instytucjonalny, tożsamość oraz zdolności do aktywnej roli międzynarodowej, zależeć będzie dalszy los Europy. Czy stanie się ona w ciągu kilkudziesięciu następnych lat Grecja, Szwajcarią czy Francja, tzn. muzeum niefrasobliwości, twierdzą Europa lub gasnąca, choć nadal pyszną metropolią. Jeśli nie potrafimy tego uczynić, pójdziemy w kierun$\mathrm{ku}$ jednej z tych trzech opcji. Jeśli wykażemy mądrość, odwagę i inteligencję pozostaniemy Europą na miarę jej obecnego, nadal imponującego potencjału i wielkiej historii - jednym z trzech ośrodków ciężkości globalnego porządku międzynarodowego. Także tu w Polsce musimy mieć świadomość wyzwań stojących przed Europa, której stajemy się integralną częścią. Także od naszej determinacji zależeć będzie los przyszłej Europy.

3. Niezmiennym od geopolitycznego zwrotu z okresu 1989-1991 wyzwaniem dla Polski jest europeizacja krajów leżących na wschód od Polski. Jeszcze nawet w połowie poprzedniej dekady można było sądzić, że większość z nich będzie stopniowo, choć niekonsekwentnie przybliżać się do UE w sensie przemian wewnętrznych oraz związków dwustronnych (ich polityki zagranicznej). Tak się nie stało. Pomijając Rosję, która trwale „pozycjonuje się” w opozycji wobec Europy (Zachodu), w ostatnich latach doszło w tych państwch do regresu w procesie zapoczątkowanych wcześniej reform oraz do geopolitycznego zwrotu ku Rosji (pod jej silną presja). Zaczęła się pogłębiać przepaść pomiędzy UE, w tym państwami byłego bloku sowieckiego, które wstapiły do Unii, a Europa Wschodnia pod względem ustroju gospodarczego (postsowiecko-oligarchicznego) i politycznego (autorytarnego). Dotyczy to zwłaszcza Białorusi, Ukrainy, Armenii. Polityczny wybór Mołdowy i Gruzji jest niezdecydowany. Należy podkreślić, że chodzi o państwa leżące w Europie i zarazem należące do naszego bezpośredniego sasiedztwa.

Wyzwanie dla Polski polega na utrzymaniu Europy Wschodniej jako Europy czy też przy Europie. Powody są trojakiego rodzaju: solidarność ze społeczeństwami tych krajów, interes stosunków dwustronnych oraz perspektywa europejska, czyli dążenie do jedności całej Europy. Ze względów bezpieczeństwa, upowszechniania demokracji i praw człowieka oraz gospodarki rynkowej Polska nie może się nie angażować w swoim bezpośrednim sąsiedztwie. Idea jagiellońska ma z tym niewiele wspólnego. Jest to także interes europejski i Polska powinna starać się to czynić wespół z innymi państwami. Świadectwem tego rodzaju zaangażowania jest Partnerstwo Wschodnie, program UE zainicjowany przez Polskę i Szwecję. W krajach objętych Partnerstwem procesy polityczne, których źródłem jest ich kulturowa odrębność, postkomunistyczne dziedzictwo oraz zależność od Rosji, utrudniają osiaganie celów i realizację zadań programu. Potwierdził to spektakularny odwrót Ukrainy od podpisania umowy o stowarzyszeniu z UE, tuż przed szczytem Partnerstwa w Wilnie, w listopadzie 2013 r. Tego rodzaju porażki nie mogą odwieść Polski od aktywności motywowanej wymienionymi wyżej względami. Historia i geopolityka oraz udział w europejskiej misji będą od nas nadal wymagać prowadzenia długofalowej, inteligentnej polityki, która będzie sprzyjać demokratycznym aspiracjom narodów Europy Wschodniej. Porażki, niekonsekwen- 
cje, frustracje towarzyszace temu procesowi z jednej strony oraz historyczny, sienkiewiczowski sentyment $-\mathrm{z}$ drugiej, moga niekiedy emocjonalnie destabilizować polskie podejście do tego zadania. Tymczasem to, co jest potrzebne, to spokojna, organiczna, pozbawiona tromtadracji i harcownictwa praca na rzecz proeuropejskich przeobrażeń w Europie Wschodniej. Trzeba będzie tu umieć łączyć prometeizm na poziomie pozarządowym (choć wspierany przez rzą) ze zręcznością Talleyranda w stosunkach dyplomatycznych, czyli na poziomie międzypaństwowym. I będziemy musieli przy tym umieć wytłumaczyć partnerom z UE, że to nie to samo, co robi Francja wobec Afryki czy Hiszpania wobec Ameryki Łacińskiej, w naszym przypadku bowiem chodzi o coś więcej o „zszywanie” Europy.

$$
* * *
$$

Nasza zdolność do stawiania czoła wyzwaniom, które wynikają z naszej przynależności do Europy, zależy od tego, w jakim stopniu czujemy się Europejczykami, jak dalece potrafimy się z Europą i jej przyszłością identyfikować. Czy potrafimy być tylko skutecznym biorca finansowej pomocy od Europy, czy dojrzeliśmy także do tego, aby brać za nią odpowiedzialność? Na to pytanie nie ma jednoznacznej odpowiedzi. Zacytujmy w tym miejscu opinię życzliwego Polsce wybitnego amerykańskiego analityka - Zbigniewa Brzezińskiego:

Największym problemem w dzisiejszej Polsce jest brak powszechnej identyfikacji z Europa. Polacy wcale nie czują się Europejczykami, choć oczywiście jest pewna moda - szczególnie w wyższych sferach - na przedstawianie się jako Europejczycy. Tylko, że to poczucie identyfikacji jest stosunkowo płytkie. Wiadomo, jeśli w grę wchodzą bezpośrednie korzyści finansowe płynace z Brukseli, to jak najbardziej - polscy politycy są wtedy szczytem europejskości. Jednak takie mentalne uciekanie od Europy, od politycznej integracji zmniejsza zdolności Polski do bycia kluczowym graczem w ramach europejskiej konstelacji ${ }^{11}$.

prof. dr hab. Roman Kuźniar

Uniwersytet Warszawski

oraz Doradca Prezydenta RP

\section{CHALLENGES FACING POLAND - 25 YEARS AFTER REGAINING INDEPENDENCE}

Summary

The twenty five years of sovereignty after the fall of the communist system has been Poland's success both in terms of internal, economic and political transformation as well as foreign policy and its role in international politics. These achievements, however, have not changed the fact that there is still much more to do. No nation, at no moment of existence is free from new challenges. The internal challenges that Poland must face today include ascertaining the functionality of the political system, further Europeanisation of Poland and implementation of European living standards, or taking necessary measures to prevent a demographic collapse. Among the external challenges, the joining of the Eurozone which is currently becoming the nucleus of European integration is of foremost priority. Poland will also have to play an active role in the shaping of the future identity of the European Union as an institution, and actively promote the European character of Eastern Europe as part of its history and consequence of its geopolitical location.

${ }_{11}$ Z. Brzeziński, Polacy nie czuja się Europejczykami (rozmawiał M. Płociński), „Rzeczpospolita" z 5 kwietnia 2013 r. 
Copyright of Journal of Law, Economics and Sociology is the property of Faculty of Law and Administration of Adam Mickiewicz University in Poznan and its content may not be copied or emailed to multiple sites or posted to a listserv without the copyright holder's express written permission. However, users may print, download, or email articles for individual use.

Właścicielem praw autorskich do „Ruchu Prawniczego, Ekonomicznego i Socjologicznego” jest Wydział Prawa i Administracji Uniwersytetu im. Adama Mickiewicza w Poznaniu. Zawartość czasopisma nie może być kopiowana, przesyłana do innych stron internetowych bądź zamieszczana na blogach bez pisemnej zgody wydawcy. Niemniej artykuły można drukować, kopiować lub przesyłać w formie elektronicznej na własny użytek. 